\title{
Presumed ocular bartonellosis
}

\author{
F T Kerkhoff, J M Ossewaarde, W S de Loos, A Rothova
}

\begin{abstract}
Background-The spectrum of diseases caused by Bartonella henselae continues to expand and ocular involvement during this infection is being diagnosed with increasing frequency.

Methods-The clinical features and visual prognosis for 13 patients with intraocular inflammatory disease and laboratory evidence of bartonellosis were investigated. There were nine patients with neuroretinitis and four with panuveitis with positive antibody titres against $B$ henselae determined by an enzyme immunoassay (IgG exceding 1:900 and/or IgM exceeding 1:250).
\end{abstract}

Results-Positive IgG levels were found for eight patients and positive IgM levels for five. Despite animal exposure of 10 patients, only two (IgG positive) cases had systemic symptoms consistent with the diagnosis of cat scratch disease. Pathological fluorescein leakage of the optic disc was observed in all affected eyes. At 6 months' follow up, 3/18 (17\%) affected eyes had a visual acuity of less than 20/100, owing to optic disc atrophy and cystoid macular oedema. 12 patients (17 eyes) were treated with antibiotics; visual acuity improved two or more Snellen lines for 9/17 (53\%) eyes.

Conclusions-The possibility of $B$ henselae infection should be considered in patients with neuroretinitis and panuveitis (especially in cases with associated optic nerve involvement) even in the absence of systemic symptoms typical for cat scratch disease.

(Br f Ophthalmol 1999;83:270-275)

F T Kerkhoff
A Rothova

Department of Internal Medicine, University Hospital Utrecht, Netherlands W S de Loos

Research Laboratory for Infectious Diseases, National Institute of Public Health and the Enviroment,

Bilthoven, Netherlands

J M Ossewaarde

Correspondence to: Frank Kerkhoff, MD, FC Donders Institute, Department of

Ophthalmology, Academic

Hospital Utrecht, PO Box

85 500, 3508 GA Utrecht, Netherlands.

Accepted for publication 14 October 1998 on the clinical features in combination with specific tests, which include skin test, histopathology of the lymph nodes, culture, polymerase chain reaction, and serological examinations - indirect fluorescence assay and enzyme immunoassay. ${ }^{8-11}$

Ocular involvement in the course of $B$ henselae infection, which is being diagnosed with increasing frequency, has been reported to be a cause of Parinaud's oculoglandular syndrome and Leber's stellate neuroretinitis (optic disc oedema and macular star). ${ }^{12-15}$ The frequency of ocular bartonellosis in a uveitic population is not known; the frequency of high positive antibody levels against $B$ henselae in patients with uveitis was $9 \%$ (6\% for IgG and $3 \%$ for $\operatorname{IgM}){ }^{16}$ In recent case reports, cat scratch disease was also related to neuroretinitis with retinal lesions, multifocal choroiditis with multiple arterial branch occlusions, serous macular detachment, and intermediate uveitis. ${ }^{17-21}$

\section{Patients and methods}

Nine patients with neuroretinitis and four with panuveitis and positive antibody titres for $B$ henselae were seen in the FC Donders Institute, University Hospital Utrecht, between January 1995 and February 1997. All patients underwent a standard diagnostic screening procedure, which consisted of erythrocyte sedimentation rate (ESR), red and white blood cell counts, serum angiotensin converting enzyme levels, syphilis, borrelia and toxoplasma serology, and chest radiography. In all 13 cases, the results of the tests were within normal limits, except for one patient with an ESR of $38 \mathrm{~mm}$ in the first hour (Table 1, no 2). An extensive medical history was obtained for each patient. Antibodies against $B$ henselae were determined by enzyme immunoassay as described by Barka et al with minor modifications. ${ }^{11}{ }^{22}$ Briefly, $B$ henselae (ATCC 49882) was used as antigen to coat microtitre plates (Greiner, medium capacity binding, Alphen a/d Rijn, The Netherlands). Before IgM analysis, IgG was removed from the serum specimens using Quick-Step IgM rProtein $\mathrm{G}$ affinity columns (Isolab, Mechelen, Belgium). Serum specimens were diluted 1:200. Rabbit anti-human IgG or rabbit anti-human IgM labelled with horse radish peroxidase was used to detect bound $\operatorname{IgG}$ or $\operatorname{IgM}$, respectively. Incubations were carried out in duplicate using antigen and control antigen and the results were compared with a dilution series of a positive reference serum to calculate the titre.

The cut off values for positive $B$ henselae serology were $\geqslant 900$ for the IgG and $\geqslant 250$ for the IgM. ${ }^{22}$ Among 60 healthy blood donors, these titres were found to be positive in two cases $(3 \%)$ for IgG and one case $(2 \%)$ for IgM. ${ }^{22}$ The first serum samples for the determination of $B$ henselae antibodies were obtained during the active stage of the ocular disease in all cases. For eight patients the diag- 
Table 1 Presumed ocular bartonellosis: clinical/laboratory characteristics, visual prognosis, and complications

\begin{tabular}{|c|c|c|c|c|c|c|c|c|c|c|}
\hline $\begin{array}{l}\text { Patient no/ } \\
\text { age/sex }\end{array}$ & $\begin{array}{l}\text { Animal } \\
\text { exposures }\end{array}$ & $\begin{array}{l}\text { Anatomical } \\
\text { diagnosis }\end{array}$ & $\begin{array}{l}\text { Uni- or } \\
\text { bilateral }\end{array}$ & $\begin{array}{l}\text { Interval between } \\
\text { onset and } \\
\text { treatment } \\
\text { (months) }\end{array}$ & $\begin{array}{l}\text { Titre before } \\
\text { treatment }\end{array}$ & $\begin{array}{l}\text { Titre after } \\
\text { treatment }\end{array}$ & $\begin{array}{l}\text { Visual acuity } \\
\text { before treatment }\end{array}$ & $\begin{array}{l}\text { Visual acuity } \\
\text { after treatment }\end{array}$ & Antibiotic* & Complications \\
\hline $1 / 15 / \mathrm{F}$ & cat & Neuroretinitis & unilateral & 1 & $\begin{array}{l}\text { IgG neg } \\
\text { IgM 1:250 }\end{array}$ & $\begin{array}{l}\text { IgG neg } \\
\operatorname{IgM}<1: 250\end{array}$ & LE CF & LE CF & $\begin{array}{l}\text { Doxycycline } \\
\text { and } \\
\text { rifampicin }\end{array}$ & $\begin{array}{l}\text { Optic nerve } \\
\text { atrophy }\end{array}$ \\
\hline $2 / 28 / \mathrm{F}$ & cat & Neuroretinitis & unilateral & 3 & $\begin{array}{l}\text { IgG 1:985 } \\
\text { IgM neg }\end{array}$ & unknown & LE 20/125 & LE $20 / 25$ & $\begin{array}{l}\text { Doxycycline } \\
\text { and } \\
\text { rifampicin }\end{array}$ & None \\
\hline $3 / 62 / \mathrm{M}$ & $\operatorname{dog}$ & Panuveitis & bilateral & 41 & $\begin{array}{l}\text { IgG 1:2000 } \\
\text { IgM neg }\end{array}$ & $\begin{array}{l}\text { IgG 1:2000 } \\
\text { IgM neg }\end{array}$ & $\begin{array}{l}\text { RE } 20 / 30 \\
\text { LE } 20 / 50\end{array}$ & $\begin{array}{l}\text { RE } 20 / 20 \\
\text { LE } 20 / 30\end{array}$ & $\begin{array}{l}\text { Doxycycline } \\
\text { and } \\
\text { rifampicin }\end{array}$ & CMO \\
\hline $4 / 28 / \mathrm{M}$ & none & Neuroretinitis & unilateral & no treatment & $\begin{array}{l}\text { IgG 1:900 } \\
\text { IgM neg }\end{array}$ & unknown & LE $20 / 200$ & LE $20 / 80$ & none & $\begin{array}{l}\text { Optic nerve } \\
\text { atrophy }\end{array}$ \\
\hline $5 / 30 / \mathrm{M}$ & none & Neuroretinitis & bilateral & 63 & $\begin{array}{l}\text { IgG } 1: 1025 \\
\text { IgM neg }\end{array}$ & $\begin{array}{l}\text { IgG } 1: 128 \\
\text { IgM neg }\end{array}$ & $\begin{array}{l}\text { RE 20/50 } \\
\text { LE 20/125 }\end{array}$ & $\begin{array}{l}\text { RE } 20 / 80 \\
\text { LE } 20 / 80\end{array}$ & $\begin{array}{l}\text { Doxycycline } \\
\text { and } \\
\text { rifampicin }\end{array}$ & $\begin{array}{l}\text { Persistent } \\
\text { choroidal } \\
\text { folds }\end{array}$ \\
\hline $6 / 53 / F$ & cat, dog & Neuroretinitis & unilateral & 13 & $\begin{array}{l}\text { IgG neg } \\
\text { IgM 1:260 }\end{array}$ & $\begin{array}{l}\text { IgG neg } \\
\text { IgM 1:261 }\end{array}$ & RE CF & RE $20 / 60$ & $\begin{array}{l}\text { Doxycycline } \\
\text { and } \\
\text { rifampicin }\end{array}$ & $\begin{array}{l}\text { Partial optic } \\
\text { nerve } \\
\text { atrophy }\end{array}$ \\
\hline $7 / 65 / \mathrm{F}$ & $\operatorname{dog}$ & Neuroretinitis & unilateral & 2 & $\begin{array}{l}\text { IgG 1:1800 } \\
\text { IgM neg }\end{array}$ & $\begin{array}{l}\text { IgG } 1: 650 \\
\text { IgM neg }\end{array}$ & LE CF & LE $20 / 60$ & $\begin{array}{l}\text { Ciprofloxacin } \\
\text { hydrochloride }\end{array}$ & $\begin{array}{l}\text { Optic nerve } \\
\text { atrophy }\end{array}$ \\
\hline $8 / 54 / \mathrm{M}$ & cat & Neuroretinitis & unilateral & 1 & $\begin{array}{l}\text { IgG 1:1036 } \\
\text { IgM neg }\end{array}$ & $\begin{array}{l}\text { IgG 1:200 } \\
\text { IgM neg }\end{array}$ & RE $20 / 50$ & RE 20/40 & $\begin{array}{l}\text { Doxycycline } \\
\text { and } \\
\text { rifampicin }\end{array}$ & $\begin{array}{l}\text { Optic nerve } \\
\text { atrophy }\end{array}$ \\
\hline 9/79/M & cat & Neuroretinitis & unilateral & 4 & $\begin{array}{l}\text { IgG 1:911 } \\
\text { IgM neg }\end{array}$ & unknown & RE 20/100 & RE $20 / 60$ & $\begin{array}{l}\text { Doxycycline } \\
\text { and } \\
\text { rifampicin }\end{array}$ & $\begin{array}{l}\text { Optic nerve } \\
\text { atrophy }\end{array}$ \\
\hline $10 / 35 / F$ & cat & Neuroretinitis & unilateral & 7 & $\begin{array}{l}\text { IgG 1:1200 } \\
\text { IgM neg }\end{array}$ & $\begin{array}{l}\text { IgG 1:926 } \\
\text { IgM neg }\end{array}$ & RE $20 / 125$ & RE CF & $\begin{array}{l}\text { Doxycycline } \\
\text { and } \\
\text { rifampicin }\end{array}$ & $\begin{array}{l}\text { Optic nerve } \\
\text { atrophy }\end{array}$ \\
\hline $11 / 40 / \mathrm{F}$ & none & Panuveitis & bilateral & 114 & $\begin{array}{l}\text { IgG neg } \\
\text { IgM 1:350 }\end{array}$ & $\begin{array}{l}\text { IgG neg } \\
\operatorname{IgM}<1: 250\end{array}$ & $\begin{array}{l}\text { RE } 20 / 80 \\
\text { LE } 20 / 60\end{array}$ & $\begin{array}{l}\text { RE 20/25 } \\
\text { LE 20/25 }\end{array}$ & $\begin{array}{l}\text { Clarithro- } \\
\text { mycin }\end{array}$ & Cataract \\
\hline $12 / 45 / \mathrm{M}$ & $\operatorname{dog}$ & Panuveitis & bilateral & 44 & $\begin{array}{l}\text { IgG neg } \\
\text { IgM } 1: 250\end{array}$ & $\begin{array}{l}\text { IgG neg } \\
\text { IgM 1:360 }\end{array}$ & $\begin{array}{l}\text { RE } 20 / 20 \\
\text { LE } 20 / 100\end{array}$ & $\begin{array}{l}\text { RE } 20 / 25 \\
\text { LE } 20 / 30\end{array}$ & $\begin{array}{l}\text { Doxycycline } \\
\text { and } \\
\text { rifampicin }\end{array}$ & $\begin{array}{l}\text { Retinal } \\
\text { pucker LE }\end{array}$ \\
\hline $13 / 50 / \mathrm{M}$ & cat & Panuveitis & bilateral & 83 & $\begin{array}{l}\text { IgG neg } \\
\text { IgM 1:270 }\end{array}$ & $\begin{array}{l}\text { IgG neg } \\
\operatorname{Ig} M<1: 250\end{array}$ & $\begin{array}{l}\text { RE } 20 / 80 \\
\text { LE } 20 / 40\end{array}$ & $\begin{array}{l}\text { RE } 20 / 100 \\
\text { LE } 20 / 30\end{array}$ & $\begin{array}{l}\text { Ciprofloxacin } \\
\text { hydrochloride }\end{array}$ & $\begin{array}{l}\text { Persistent } \\
\text { CMO }\end{array}$ \\
\hline
\end{tabular}

*The following dosages were used: 1 clarithromycin, $2 \times 250 \mathrm{mg} /$ day for 2 weeks; 2 ciprofloxacin hydrochloride, $2 \times 250 \mathrm{mg} /$ day for 2 weeks; 3 doxycycline, loading dose of $2 \times 100 \mathrm{mg}$ first day, followed by $1 \times 100 \mathrm{mg} /$ day for 4 weeks; and rifampicin, $1 \times 600 \mathrm{mg} /$ day for 4 weeks.

$\mathrm{CF}=$ counting fingers; $\mathrm{CMO}=$ cystoid macular oedema.

nosis was established retrospectively, using stored serum samples which had been collected during the active stage of their ocular disease. The determination of antibodies against $B$ henselae is not a routine procedure for all patients with uveitis of unknown origin in our institute; the decision was dictated by the awareness of the ophthalmologist involved and the availability of a stored serum sample.

In this study, neuroretinitis was defined as optic disc swelling associated with peripapillary and/or macular oedema without signs of optic nerve compression or elevated intracranial pressure. ${ }^{23}$ Panuveitis was considered in cases with inflammatory cells in both anterior and posterior eye segment, with or without chorioretinal disease. ${ }^{24}$ All patients underwent fluorescein angiography and eight underwent repeated visual field examinations.

\section{Results}

The general characteristics of the patients are given in Table 1 . The mean age of the 13

Table 2 Ocular features in presumed ocular bartonellosis

\begin{tabular}{lll}
\hline Ocular features & $\begin{array}{l}\text { Panuveitis } \\
(n=4)\end{array}$ & $\begin{array}{l}\text { Neuroretinitis } \\
(n=9)\end{array}$ \\
\hline Aqueous cells & 4 & 6 \\
Posterior synechiae & 2 & 1 \\
Vitreous cells & 4 & 6 \\
$\begin{array}{l}\text { Exudative maculopathy or cystoid } \\
\quad \text { macular oedema }\end{array}$ & 3 & 6 \\
Papillitis & 4 & 9 \\
Retinal lesions & 1 & 3 \\
Vasculitis & 2 & 1 \\
\hline
\end{tabular}

patients (seven males and six females) was 45 years (range 15-79 years). The mean follow up was 44 months (9-135 months). Exposure to cats or dogs before the ocular disease was reported by 10 patients. Only two patients (Table 1, nos 1 and 3 ) had systemic symptoms characteristic of cat scratch disease-that is, otherwise unexplained fever, malaise, and lymphadenopathy; one was also positive for antiphospholipid antibodies.

The ocular features are presented in Table 2 ; nine patients suffered from neuroretinitis (Figs 1 and 2), the remaining four patients had panuveitis. Nearly all (8/9) neuroretinitis patients had unilateral disease; bilateral involvement was exhibited by all patients with panuveitis, resulting in 18 affected eyes. Independent of the predominant location of the inflammatory activity, all affected eyes showed pathological fluorescein leakage of the optic disc. At presentation, 9/18 (50\%) affected eyes had a visual acuity of less than $20 / 100$. None of the patients had symptoms of redness, pain, or photophobia and all had normal intraocular pressure. At 6 months' follow up, 3/18 (17\%) affected eyes still had a visual acuity of less than 20/100. The causes of permanent visual loss were predominantly optic nerve atrophy and cystoid macular oedema. Visual field defects persisted in all 11 tested eyes. The visual prognosis for patients with neuroretinitis and panuveitis did not differ significantly. Focal retinal lesions were present in four 

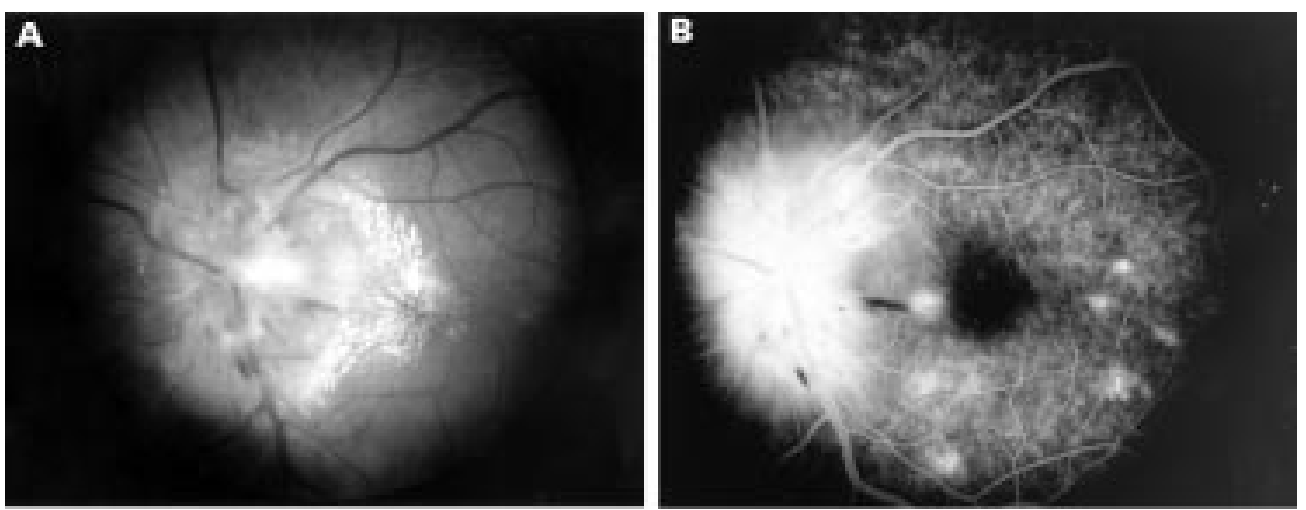

Figure 1 Neuroretinitis in presumed ocular bartonellosis. (A) Fundus photograph showing extremely swollen optic disc with haemorrhages and macular star (patient no 4, Table 1). (B) Fluorescein angiogram showing hyperfluorescent optic nerve with peripapillary leakage of fluorescein and hyperfluorescent retinal lesions in posterior pole.

patients; in two cases these were located within the large vascular arcades.

Of the 13 patients positive for antibodies against $B$ henselae, five were $\operatorname{Ig} M$ positive (Table 1, two with neuroretinitis and three with panuveitis). The visual prognosis and reactions to therapy did not differ between patients with positive antibody titres for $\operatorname{IgM}$ or IgG (Table 1 ). In $1 / 5 \operatorname{IgM}$ positive patients and in $4 / 8 \mathrm{IgG}$ positive patients the diagnosis was made within 4 months after the onset of the ocular disease; in all other eight patients the diagnosis was made after a substantial delay (average 51 months, range 6-114
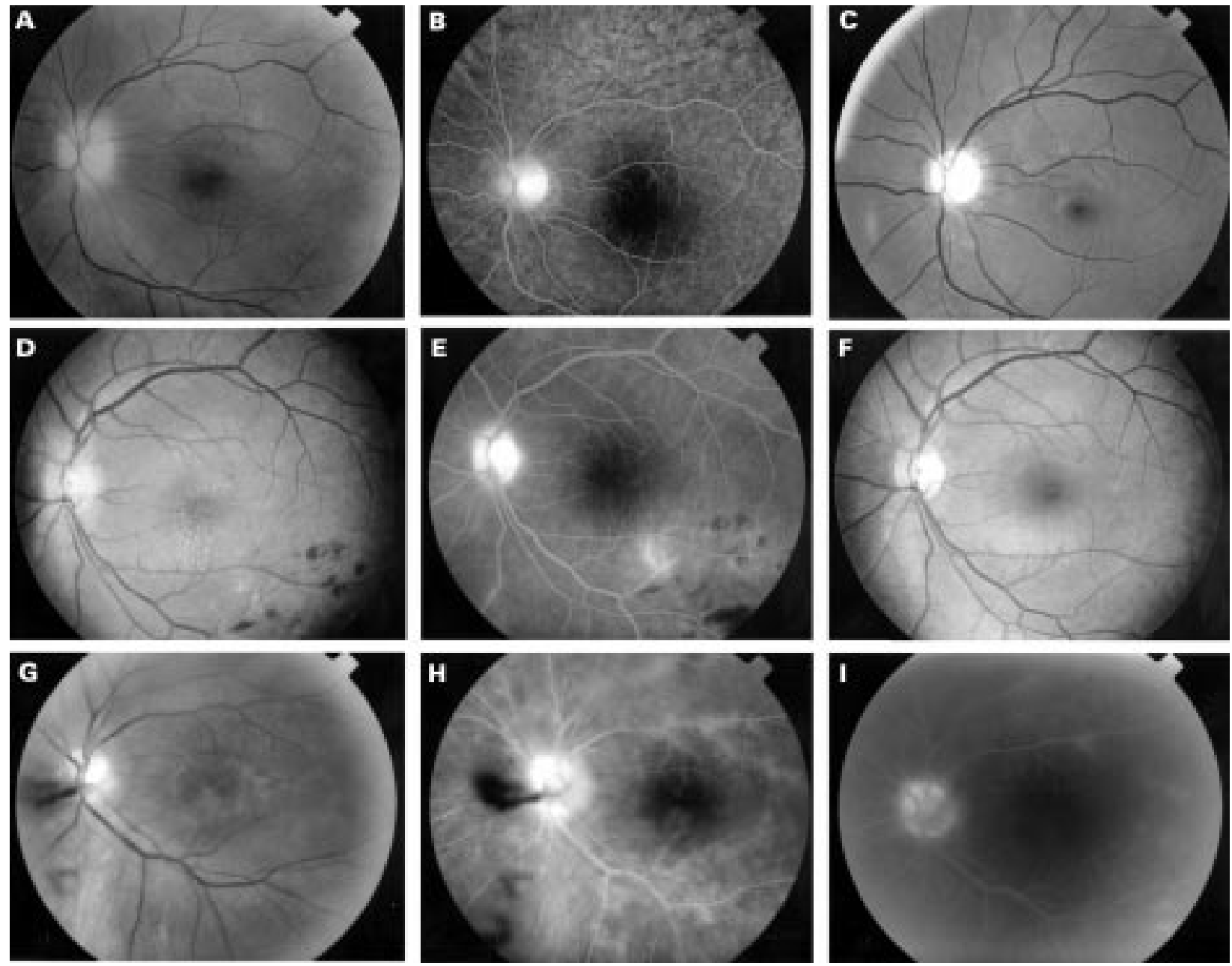

Figure 2 Case reports. Case 1. (A) Fundus photograph showing swollen, pale optic nerve. (B) Fluorescein angiogram showing hyperfluorescent optic disc with discrete peripapillary leakage. (C) Fundus photograph showing optic nerve atrophy which developed despite treatment with antibiotics. Case 2. (D) Fundus photograph showing slight oedema of optic disc and nerve fibre layer, macular star with alterations of foveal pigment epithelium, discrete macular oedema, and branch retinal vein obstruction. (E) Fluorescein angiogram documenting hyperfluorescent optic nerve and branch retinal vein obstruction. (F) Fundus photograph following antibiotic treatment showing discrete temporal pallor of optic nerve and alterations in foveal pigment epithelium. Case 3. (G) Fundus photograph showing vitreous haze and and local vitreous haemorrhage. (H) Fluorescein angiogram documenting hyperfluorescent optic nerve and retinal vasculitis. (I) Fluorescein angiogram following antibiotic treatment showing decrease in hyperfluorescence of the optic nerve and decrease in retinal vasculitis. 
months). Therefore, 10 patients were initialy treated with periocular or systemic corticosteroids, which decreased the intraocular inflammation in nine patients; however, one patient developed a rapid visual loss. Twelve patients (17 eyes) received antibiotics during the active stage of the disease (Table 1). In eight of these 12 patients the ocular disease was chronic with a duration of more than 6 months. After antibiotic treatment ocular inflammation subsided in all patients, except for two with chronic ocular disease (Table 1, patients 10 and 11). No ocular or systemic side effects of the antibiotics were observed. No differences between the various therapies were observed. Visual acuity improved in 9/17 $(53 \%)$ eyes with two or more Snellen lines. Follow up antibody levels (3 months after treatment) were available for 9/12 treated patients; a decrease in antibody levels was documented in six cases. No relation between the decrease in antibodies and activity of ocular disease was noted.

CASE REPORTS

Case 1

A 15 year old female patient (Table 1, no 1) was referred to our clinic with neuroretinitis of the left eye together with rapid deterioration of the visual acuity (from 20/20 to counting fingers in 3 days) despite treatment with systemic prednisone (initial dose $60 \mathrm{mg}$ per day). She had lived on a farm with many kittens. On examination, we found a mildly hyperaemic left optic disc without any signs of inflammatory activity in the vitreous (Fig 2, case 1). No abnormalities were noted on neurological examination: cerebrospinal fluid examination revealed a mild pleiocytosis and no oligoclonal protein bands. Serum IgM antibodies against $B$ henselae were positive in a titre of 1:250; in the cerebrospinal fluid, however, these specific antibodies were not detected. Despite treatment with doxycycline and rifampicin, visual acuity did not improve and optic nerve atrophy occurred.

Case 2

A 28 year old female (Table 1, no 2) complained of headaches and decreased vision of the left eye with an acuity of 20/125. On presentation, the aqueous and vitreous both contained inflammatory cells. The optic disc was swollen and hyperaemic with an associated macular star, retinal haemorrhages, and vasculitis (Fig 2, case 2). The patient owned two cats. Laboratory examination revealed an elevated erythrocyte sedimentation rate and an IgG titre of 1:985 for $B$ henselae. Treatment with doxycycline and rifampicin was initiated and acuity improved to $20 / 25$.

Case 3

A 65 year old male patient (Table 1 , no 3 ) had had idiopathic panuveitis in both eyes for 2 years, characterised by inflammatory cells in the aqueous and vitreous, hyperaemic optic disc, and retinal vasculitis (Fig 2, case 3 ). The visual acuity was $20 / 50$ in the left eye and $20 / 30$ in the right eye. His medical history included a period of fever and lymphadenopathy, 10 years before the onset of his ocular symtoms. Laboratory examination revealed IgG antibodies against $B$ henselae in a titre of $1: 2000$. The patient owned a dog. He was subsequently treated with doxycycline and rifampicin. Because of persistent cystoid macular oedema he was also treated with periocular steroids. The visual acuity increased to $20 / 30$ in the left eye and 20/20 in the right eye.

\section{Discussion}

The ocular features of our patients with neuroretinitis were similar to those attributed to bartonellosis in previous reports. ${ }^{13}{ }^{14}$ In the past, sporadic ocular involvement (mainly neuroretinitis) had been noted during the course of generalised cat scratch disease. ${ }^{13142526}$ Various reports on ocular disease followed with associated (sometimes borderline) positive antibody titres for $B$ henselae. The latter cases usually had a negative history for cat scratches and exhibited no symptoms or signs typical for generalised cat scratch disease. ${ }^{1821}$ Therefore, some of these patients may not have suffered from bartonellosis. A study by Wong et al revealed that neuroretinitis was the second most frequent presentation of $B$ henselae infection (unilateral regional lymphadenopathy was the most frequent presentation), and they reported three patients with isolated unilateral neuroretinitis and concurrent bacteraemia. ${ }^{27}$

An ophthalmological diagnosis based solely on the interpretation of serological tests (in the absence of generalised disease) may be troublesome, since false positive and false negative serological reactions occur. Specifically, moderately high titres of IgG antibodies were frequently found in healthy blood donors or in asymptomatic family members of patients with cat scratch disease. ${ }^{32}$ However, our laboratory data suggest that our patients had indeed been infected with $B$ henselae, since the cut offs ( IgG 1:900 and $\operatorname{IgM} 1: 250$ ) were set extremely high to obtain a specificity of $97 \%$ and $98 \%$ for the diagnosis of $B$ henselae infection. ${ }^{22}$ The question whether $B$ henselae is present in the eye and directly causing ocular infection or whether ocular involvement represents a secondary autoimmune reaction initiated by the systemic infection cannot be answered yet. The ultimate proof of $B$ henselae as a direct cause of ocular disease would be to demonstrate the presence of the infectious agent in the eye. This has been achieved once by PCR analysis of a retinal lesion in an HIV infected patient. ${ }^{28}$ Also $B$ henselae DNA was found in an conjunctival lesion in an HIV infected patient. ${ }^{29}$ Future studies which include PCR analysis of intraocular or cerebrospinal fluids may clarify this point.

Nine of 13 patients with high positive $B$ henselae serology exhibited the classic picture of neuroretinitis and three of these patients also had focal retinal lesions. The remaining four patients had panuveitis. In our series one patient with neuroretinitis and one with panuveitis exhibited generalised features typical of systemic cat scratch disease. This indicates 
that even in the absence of typical systemic symptoms bartonellosis should be included in the differential diagnosis of patients with neuroretinitis and non-specific panuveitis. Because of the low frequency of bartonellosis in uveitis patients testing for $B$ henselae is not recommended during the initial screening. ${ }^{16}$

In our study the interval between onset of ocular disease and the serological tests varied. If our patients with positive serological results indeed suffered from ocular bartonellosis, our findings suggest that ocular disease may occur late in the course of the infection, since eight patients developed ocular involvement in the absence of specific IgM. Also the data suggest that in some cases specific IgM can persist after the onset of the ocular disease. However, we do not have laboratory data on the decline of the specific antibodies in the course of ocular bartonellosis.

Treatment strategies for patients with neuroretinitis in general are not exactly defined. Corticosteroids have been used to alleviate the associated inflammatory reaction. ${ }^{30}$ However, visual outcome was not influenced by the use of systemic steroids, which was also observed in our series. ${ }^{30}$ As in previous series, the visual prognosis of neuroretinitis was relatively benign since significant visual loss persisted in two of 10 affected eyes (6 months' follow up). ${ }^{31} 32$ The visual prognosis of $B$ henselae related panuveitis was better since seven of eight affected eyes achieved a visual acuity of $20 / 30$ or more (6 months' follow up).

The role of antimicrobial therapy in cat scratch disease is controversial, since this disease may follow a prolonged but self limiting course. ${ }^{33-35} \mathrm{~A}$ wide variety of antimicrobial agents has been recommended for patients with cat scratch disease; clinical studies suggest that prolonged courses of doxycycline and rifampicin may be safe and effective. ${ }^{27}$ In a study by Reed et al doxycycline and rifampicin also promotes the resolution of cat scratch disease related neuroretinitis. ${ }^{36}$ Although various therapies were used in our study, we observed no further progression of the ocular disease in 10 of 12 patients after antibiotic treatment. We do not know if this effect is due to the antibiotics or to the self limiting course of the disease; in $6 / 8$ cases with chronic disease, no more ocular inflammation was seen after treatment perhaps suggesting an additional effect of antibiotics. Future studies will need to clarify the role of antibiotics in ocular bartonellosis.

Our understanding of the pathogenesis of $B$ henselae infections is incomplete and the spectrum of Bartonella related diseases continues to expand. This report adds a series of nine patients with neuroretinitis and four patients with panuveitis with presumed ocular bartonellosis to the occasional case reports. The ocular features of our patients and their laboratory data suggest a distinct clinical entity possibly caused by $B$ henselae. We conclude that $B$ henselae infection should be included in the differential diagnosis for patients with neuroretinitis and panuveitis (especially in cases with associated optic nerve involvement) even in the absence of systemic symptoms typical for cat scratch disease. The correct diagnosis of this infectious cause of uveitis at an early stage and subsequent antibiotic treatment may improve the visual outcome for these patients.

1 Adal KA, Cockerell CJ, Petri WA. Cat scratch disease, bacillary angiomatosis, and other infections due to Rochaliillary angiomatosis, and other infections

2 Jerris RC, Regnery RI. Will the real agent of cat-scratch disease please stand up? Ann Rev Microbiol 1996;50:707-25.

3 Zangwill KM, Hamilton DH, Perkins BA, et al. Cat scratch disease in Connecticut. Epidemiology, risk factors, and evaluation of a new diagnostic test. $N$ Engl $\mathcal{F} \mathrm{Med}$ 1993;329:8-13.

4 Koehler JE, Glaser CA, Tappero JW. Rochalimaea henselae infection. A new zoonosis with the domestic cat as reservoir. $\mathcal{F A M A}$ 1994;7:531-5.

5 Pappalardo BL, Correa MT, York CC, et al. Epidemiologic evaluation of the risk factors associated with exposure and seroreactivity to Bartonella vinsonii in dogs. Am 7 Vet Res 1997;58:467-71.

6 Baneth G, Breitschwerdt EB, Hegarty BC, et al. A survey of tick-borne bacteria and protozoa in naturally exposed dogs from Israel. Vet Parasitol 1998;74:133-42.

7 Schwartzman WA. Infections due to rochalimaea: the expanding clinical spectrum. Clin Infect Dis 1992;15:893900 .

8 Carithers HA, Carithers CM, Edwards RO. Cat scratch disease. FAMA 1996;207:312-16.

9 Anderson B, Kelly C, Threlkel R, et al. Detection of Rochalimea henselae in cat-scratch disease skin test antigens. $\mathcal{F}$ Infect Dis 1993;168:1034-6.

10 Regnery RL, Olson JG, Perkins BA, et al. Serological response to Rochalimaea henselae antigen in suspected cat-scratch disease. Lancet 1992;339:1443-5.

11 Barka NE, Hadfield T, Patnaik M, et al. EIA for detection of Rochalimea henselae-reactive IgG, IgM, and IgA antibodies in patients with suspected cat-scratch disease. F Infect Dis 1993;167:1503-4.

12 Carithers HA. Oculoglandular disease of Parinaud. $A m \mathcal{F}$ Dis Child 1978;132:1195-200.

13 Chrousos GA, Drack AV, Young M, et al. Neuroretinitis in cat scratch disease. $\mathcal{F}$ Clin Neuro-ophthalmol 1990;10:92-4.

14 Bar S, Segal M, Shapira R, et al. Neuroretinitis associated Bar S, Segal M, Shapira R, et al. Neuroretinitis associated
with cat scrath disease. Am 7 Ophthalmol 1990;110:703-7.

15 Ulrich GG, Waecker NJ, Meister SJ, et al. Cat scratch disease associated with neuroretinitis in a 6 year-old girl. Ophthalmology 1991;99:246-9.

16 Rothova A, Kerkhoff FT, Hooft HJ, et al. Bartonella serology for patients with intraocular inflammatory disease. Retina 1998;18:348-55.

17 Golnik KC, Marotto ME, Fanous MM, et al. Ophthalmic manifestations of rochalimaea species. Am f Ophthalmol 1994;118:145-51.

18 Cohen SM, Davis JL, Gass DM. Branch retinal arterial occlusion in multifocal retinitis with optic nerve edema. Arch Ophthalmol 1995;113:1271-6.

19 Fisch RH, Hogan RN, Nightengale SD, et al. Peripapillary angiomatosis associated with cat-scratch disaese. Arch Ophthalmol 1992;110:323.

20 Zacchei AC, Newman NJ, Sternberg P. Serous retinal detachement of the macula associated with cat scratch disdetachement of the macula associated with

21 Soheilian M, Markomichelakis N, Foster CS. Intermediate uveitis and retinal vasculitis as manifestations of cat scratch disease. Am f Ophthalmol 1996;122:582-3.

22 Bergmans AMC, Peeters MF, Schellekens JFP, et al. Pitfalls and fallacies of cat scratch disease serology: evaluation of Bartonella henselae-based indirect fluorescence assay and enzyme-linked immunoassy. F Clin Microbiol 1997;35: 1931-7.

23 Gyer DR, D'Amico DJ. Leber's stellate idiopathic neuroretinitis. In: Albert DM, Jacobeic FA, eds. Principals and practice of ophthalmology: clinical practice. Philadelphia: WB Saunders, 1994:809-13.

24 Bloch-Michel E, Nussenblatt RB. International Uveitis Study Group Recommendations for the evaluation of intraocular inflammatory disease (letter). Am f Ophthalmol 1987;103:234-5.

25 Newsom RW, Martin TJ, Wasilauskas B. Cat-scratch disease diagnosed serologically using an enzyme immunoassay in a patient with neuroretinitis. Arch Ophthalmol 1996;114:493-

26 Bafna S, Lee AG. Bilateral optic disc edema and multifocal retinal lesions without loss ofsion in cat scratch disease. Arch Ophthalmol 1996;114:1016-17.

27 Wong MT, Dolan MJ, Lattuada CP, et al. Neuroretinitis, aseptic meningitis, and lymphadenitis associated with Bartonella henselae infection in immunocompetent patients and patients infected with human immunodeficiency virus type 1. Clin Infect Dis 1995;21:352-60.

28 Warren K, Goldstein E, Hung VS, et al. Use of retinal biopsy to diagnose Bartonella (formerly rochalimaea) henselae retinitis in an HIV-infected patient. Arch Ophthalmol 1998; 116:937-40.

29 Hung HL, Palay DA, Anderson B, et al. Conjunctival swab to diagnose ocular cat scratch disease. Am $\mathcal{f}$ Ophthalmol 10 diagnose ocular cat scratch disease. Am f Ophthalmol

30 Purvin VA, Chorian G. Recurrent neuroretinitis. Arch Ophthalmol 1994;112:365-71. 
31 Dreyer RF, Hopen G, Gass DM, et al. Leber's idiopathic stellate neuroretinitis. Arch Ophthalmol 1984;102:1140-5. 32 Maitland CG, Miller NR. Neuroretinitis. Arch Ophthalmol

33 Maurin M, Gasquet S, Ducco C, et al. MICs of 28 antibiotic compounds for 14 Bartonella isolates. Antimicrob Agents Chemother 1995;39:2387-91.

34 Maurin M, Raoult D. Antimicrobial susceptibility of Rochalimea quintana, Rochalimea vinsonii, and the newly recognized Rochalimea henselae. Antimicrob Agents Chem-

other 1993;32:587-94.
35 Margileth AM. Antibiotic therapy for cat-scratch disease: clinical study of therapeutic outcome in 268 patients and 8 .

36 Reed JB, Scales DK, Wong MT, et al. Bartonella henselae neuroretinitis in cat scratch disease. Ophthalmology 1998; 105:459-66. 